\title{
AKTIVITAS ANTIOKSIDAN HIDROLISAT KOLAGEN KULIT IKAN NILA (Oreochromis niloticus)
}

\author{
Deny Tri Prastyo ${ }^{\star}$, Wini Trilaksani, Nurjanah \\ Departemen Teknologi Hasil Perairan, IPB University, Jalan Agatis, Kampus IPB Dramaga 16680 Bogor \\ ${ }^{*}$ Korespondensi: wtrilaksani@apps.ipb.ac.id \\ Diterima: 18 Agustus 2020/Disetujui: 04 November 2020
}

Cara sitasi: Prastyo DT, Trilaksani W, Nurjanah. 2020. Aktivitas antioksidan hidrolisat kolagen kulit ikan nila (Oreochromis niloticus). Jurnal Pengolahan Hasil Perikanan Indonesia. 23(3): 423-433.

\begin{abstract}
Abstrak
Kulit ikan nila merupakan hasil samping proses pengolahan ikan yang dapat dimanfaatkan sebagai alternatif bahan baku kolagen dan hidrolisatnya. Hidrolisat kolagen diketahui memiliki aktivitas biologis yang potensial diantaranya sebagai antioksidan. Penelitian ini bertujuan untuk menentukan aktivitas antioksidan hidrolisat kolagen dari kulit ikan nila (Oreochromis niloticus) secara in vitro. Penelitian ini terbagi menjadi tiga tahap meliputi fase praperlakuan kolagen, ekstraksi kolagen dan hidrolisis kolagen. Pada proses hidrolisis digunakan enzim papain dengan konsentrasi yang berbeda $(4.000 \mathrm{U} / \mathrm{g}, 6.000 \mathrm{U} / \mathrm{g}$, $8.000 \mathrm{U} / \mathrm{g}$ sampel) dengan waktu hidrolisis selama 60, 120 dan 180 menit. Rerata nilai rendemen hidrolisat kolagen kulit ikan nila sebesar 15,17\%. Waktu hidrolisis, konsentrasi enzim yang diberikan serta interaksi antar kedua faktor tersebut berpengaruh secara signifikan terhadap nilai derajat hidrolisis dan aktivitas antioksidan hidrolisat kolagen kulit ikan nila. Hidrolisat kolagen kulit ikan nila yang dihidrolisis selama 120 menit dengan pemberian konsentrasi enzim sebesar 8.000 U memiliki rerata persentase derajat hidrolisis sebesar 33,94\%, serta rerata nilai $\mathrm{IC}_{50}$ terbaik yakni $93,32 \mu \mathrm{g} / \mathrm{mL}$, termasuk pada kategori senyawa antioksidan kuat. Nilai zeta potensial hidrolisat kolagen kulit ikan nila adalah -10,9 mV.
\end{abstract}

Kata kunci: ABTS, derajat hidrolisis, enzim papain, zeta potensial

\section{Antioxidant activity of Tilapia (Oreochromis niloticus) Skin Collagen Hydrolysate}

\begin{abstract}
Tilapia skin is a by-product of fish processing which can be used as an alternative raw material for collagen hydrolysate. Collagen hydrolysate is known to have biological activities including antioxidants. This study was aimed to examine the antioxidant activity of collagen hydrolysate from the skin of tilapia (Oreochromis niloticus). This research was divided into three stages including pretreatment, extraction and hydrolysis. In the hydrolysis process, papain enzymes were used with different concentrations $(4,000 \mathrm{U} / \mathrm{g}$, $6,000 \mathrm{U} / \mathrm{g}, 8,000 \mathrm{U} / \mathrm{g}$ samples) with incubation time for 60, 120 and 180 minutes. The average yield of tilapia skin collagen hydrolysate was $15.17 \%$. The hydrolysis time, the concentration of enzymes given and the interaction be-tween the two factors significantly affected the degree of hydrolysis and antioxidant activity of the hydrolyzed collagen of ti-lapia skin. Hydrolysis of collagen for 120 minutes using 8,000 U of enzyme concentration produced degree of hydrolysis of $33.94 \%$, and hydrolysate having $\mathrm{IC}_{50}$ value $93.32 \mu \mathrm{g} / \mathrm{mL}$, therefore categorized as strong antioxidant compounds. The zeta potential value of the tilapia skin collagen hydrolysate was $-10.9 \mathrm{mV}$.
\end{abstract}

Keywords: ABTS, degree of hydrolysis, papain enzyme, zeta potential 


\section{PENDAHULUAN}

Ikan nila (Oreochromisniloticus) termasuk dalam jenis ikan budi daya di Indonesia yang produksinya terus mengalami peningkatan. Data BKIPM (2019) tentang statistik ekspor perikanan menunjukkan bahwa angka ekspor produk ikan nila pada tahun 2018 mencapai 10 ribu ton yang tersebar di berbagai negara misalnya Amerika, Jerman, Belanda hingga Jepang. Pengolahan ikan nila menjadi produk filet menyisakan hasil samping kulit ikan nila dengan proporsi sebesar $8,7 \%$ dari total berat ikan (Peranginangin et al. 2006) yang berpotensi untuk dimanfaatkan sebagai sumber kolagen.

Kolagen merupakan protein jaringan ikat yang menyusun komponen bagian tubuh misalnya gigi, otot, tulang, kuku, dan kulit. Kolagen memiliki stuktur yang unik yakni struktur primernya berbentuk triple helix yang terdiri dari 3 rantai polipeptida berbentuk spiral (Kucharz 1992). Kolagen yang bersumber dari hasil samping produksi perikanan banyak diteliti sebagai alternatif pengganti kolagen komersial dari mamalia (babi dan sapi), serta untuk meningkatkan nilai fungsi dan ekonomi dari hasil samping perikanan. Pemanfaatan kolagen dalam bentuk hidrolisatnya juga banyak dieksplorasi untuk mengetahui aktivitas biologisnya yang bermanfaat bagi tubuh.

Kolagen yang dihidrolisis secara enzimatis menggunakan enzim protease akan menghasilkan hidrolisat protein kolagen yang diketahui memiliki berbagai aktivitas biologis yang bermanfaat di bidang kesehatan. Protein dalam bentuk kompleks polipeptida memiliki aktivitas biologis yang rendah dan dapat ditingkatkan melalui proses hidrolisis oleh enzim yang mengakibatkan kompleks protein terlepas dari ikatan panjang fragmennya (Murray dan Fitzgerald 2007). Wu et al. (2018) melaporkan bahwa hidrolisat kolagen dari ikan salmon memiliki aktivitas antioksidan dan antifreezing. Ahmed dan Chun (2018) melaporkan dalam penelitiannya bahwa hidrolisat kolagen kulit ikan tuna memiliki aktivitas antioksidan dan antimikroba. Hidrolisat kolagen kulit ikan nila diduga memiliki potensi aktivitas antioksidan sehingga perlu diteliti lebih lanjut.
Radikal bebas yang berasal dari lingkungan maupun pangan dapat memicu terjadinya stres oksidatif hingga pada tingkat seluler. Stres oksidatif yang terjadi secara kontinu dapat berpotensi memicu rusaknya sistem metabolisme yang menyebabkan timbulnya penyakit degeneratif. Senyawa yang mampu menangkal radikal bebas dan menghambat laju oksidasi disebut dengan antioksidan (Valko et al. 2007). Hidrolisat protein diketahui memiliki aktivitas antioksidan melalui mekanisme donor atom hidrogen sehingga mampu menghambat laju oksidasi (Mendis et al. 2005).

Beberapa penelitian sebelumnya berkaitan dengan ekstraksi kolagen dari hasil samping produksi perikanan telah dilakukan, diantaranya kolagen dari gelembung renang ikan cunang (Gadi et al. 2017), gelembung renang ikan patin (Simamora et al. 2019) dan kulit ikan nila (Ahmad et al. 2019). Mutamimah et al. (2018) melaporkan bahwa hasil samping mata tuna (Thunnus sp.) yang dihidrolisis menggunakan enzim papain memiliki aktivitas antioksidan dengan nilai $\mathrm{IC}_{50} 1,08 \pm 0,008 \mathrm{mg} / \mathrm{mL}$. Pemanfaatan hasil samping sebagai sediaan bioaktif perlu diteliti lebih lanjut.

Jumlah hasil samping produk perikanan skala industri yang melimpah menjadi alasan perlunya pemanfaatan yang optimal agar dapat meningkatkan nilai fungsi sekaligus nilai ekonomi dari suatu komoditi. Di sisi lain sediaan obat dari bahan alami diketahui memiliki lebih sedikit efek samping dibandingkan sediaan obat yang disintesis secara kimiawi, sehingga perlu terus dikembangkan. Penelitian ini bertujuan untuk menentukan aktivitas antioksidan hidrolisat kolagen dari kulit ikan nila (Oreochromis niloticus) secara in vitro.

\section{BAHAN DAN METODE Bahan dan Alat}

Bahan utama yang digunakan dalam penelitian ini adalah kulit ikan nila (O. niloticus). Bahan yang digunakan untuk ekstraksi dan hidrolisis kolagen antara lain akuades, $\mathrm{NaOH}, \mathrm{CH}_{3} \mathrm{COOH}, \mathrm{NaCl}$ dan $\mathrm{HCl}$ (Merck, Jerman), enzim papain (HiMedia, India) dan kantong dialisis (MWCO $14 \mathrm{kDa}$ ). Bahan 
untuk analisis derajat hidrolisis dan protein terlarut meliputi bovine serum albumin (BSA), coomasie briliant blue (CBB), asam ortofosfat, etanol dan trichloroacetic acid (TCA). Bahan untuk analisis antioksidan antara lain, 2,2'-azino-bis(3-ethylbenzothiazoline-6-sulfonic acid) (ABTS) (SigmaAldrich, AS), potasium persulfat dan asam askorbat. Peralatan yang digunakan dalam penelitian ini antara lain timbangan analitik (Sartorius, Jerman), pengaduk magnetik (Yamato Scientific, Jepang), sentrifuge (HIMAC CR 21G Hitachi Koki, Jepang), freeze dryer, waterbath (BT 25 Yamato, Jepang), mikropipet (Nichipet EX 1000, Jepang), Spektrofotometer UV-Vis (U2800 Hitachi, Jepang), UPLC-MS.

\section{Metode Penelitian}

Penelitian ini terbagi menjadi tiga tahapan utama, yakni optimasi fase praperlakuan kolagen, ekstraksi kolagen, dan optimasi proses hidrolisis kolagen.

\section{Praperlakuan ekstraksi kolagen (Liu et al. 2015)}

Sampel kulit ikan dicuci menggunakan air dingin $\left( \pm 4{ }^{\circ} \mathrm{C}\right)$, dipotong kecil-kecil (2-5 $\mathrm{cm})$ lalu ditimbang sebanyak 100 g. Sampel kemudian direndam menggunakan larutan $\mathrm{NaOH} 0,1 \mathrm{~N}$ dengan perbandingan sampel dan pelarut 1:10 (b/v) selama 12 jam dengan penggantian larutan setiap 2 jam untuk menghilangkan mineral dan protein nonkolagen. Sampel dibilas dengan akuades hingga $\mathrm{pH}$ air bilasan mendekati netral, kemudian direndam dalam larutan butil alkohol 10\% dengan perbandingan sampel dan pelarut 1:10 (b/v) selama 24 jam, dengan mengganti larutan setiap 12 jam untuk menghilangkan kandungan lemak pada kulit ikan.

\section{Ekstraksi kolagen (Liu et al. 2015)}

Serat kolagen kasar yang dihasilkan dari fase praperlakuan diekstraksi dalam larutan asam asetat $0,5 \mathrm{M}$ dengan perbandingan 1:30 (b/v) selama 48 jam. Larutan sampel selanjutnya disentrifugasi dengan kecepatan $10.000 \mathrm{~g}$ selama 30 menit pada suhu $4{ }^{\circ} \mathrm{C}$. Supernatan dipisahkan dan disimpan pada suhu $4{ }^{\circ} \mathrm{C}$ untuk dipresipitasi menggunakan $\mathrm{NaCl}$ dengan konsentrasi 0,9 M selama 12 jam. Larutan sampel kemudian disentrifugasi dengan kecepatan $10.000 \mathrm{~g}$ selama 30 menit pada suhu $4{ }^{\circ} \mathrm{C}$. Presipitat dikumpulkan dan dilarutkan dalam larutan asam asetat 0,5 M (1:1), kemudian didialisis menggunakan membran dialisis $(14 \mathrm{KDa})$ terhadap asam asetat $0,1 \mathrm{M}$ selama 24 jam, dilanjutkan dialisis terhadap akuades selama 24 jam dengan mengganti larutan asam asetat dan akuades setiap 4 jam sekali. Kolagen basah yang dihasilkan kemudian dikeringkan menggunakan freeze dryer.

\section{Hidrolisis kolagen (Zhang et al. 2013; Najafian dan Babji 2014)}

Sampel kolagen sebanyak $1 \mathrm{~g}$ dilarutkan ke dalam $100 \mathrm{~mL}$ akuades lalu diinkubasi pada $\mathrm{pH} 7$, suhu $50{ }^{\circ} \mathrm{C}$ selama 15 menit untuk selanjutnya ditambahkan enzim papain (4.000 U/g, $6.000 \mathrm{U} / \mathrm{g}, 8.000 \mathrm{U} / \mathrm{g}$ sampel) dan dihidrolisis selama 60, 120 dan 180 menit. Reaksi dihentikan dengan memanaskan sampel pada suhu $90{ }^{\circ} \mathrm{C}$ selama 15 menit kemudian langsung didinginkan selama 20 menit di atas es. Sampel disentrifugasi menggunakan kecepatan 10.000 g selama 20 menit pada suhu $4{ }^{\circ} \mathrm{C}$. Supernatan yang didapatkan selanjutnya disaring menggunakan kertas saring (whatman no. 4) dan dikeringkan menggunakan freeze dryer.

\section{Derajat hidrolisis (Silvestree et al. 2013)}

Persentase derajat hidrolisis (DH) dihitung melalui pengendapan trichloroacetic acid (TCA) pada konsentrasi 20\% yang memisahkan fraksi protein terlarut dan dan tidak terlarut masing-masing sebesar $10 \%$. Sampel hidrolisat kolagen diambil sebanyak $500 \mu \mathrm{L}$ dan dihomogenkan dengan $500 \mu \mathrm{L}$ TCA 20\% kemudian diinkubasi selama 30 menit pada suhu $4{ }^{\circ} \mathrm{C}$. Sampel kemudian disentrifuse pada kecepatan $3.000 \mathrm{~g}$ selama 20 menit. Supernatan diambil dan dianalisis kandungan protein terlarutnya berdasarkan metode Lowry et al. (1951). Bovine serum albumin (BSA) digunakan sebagai standar protein. Persentase derajat hidrolisis dapat dihitung menggunakan rumus berikut:

$\mathrm{DH}(\%)=\frac{\text { Protein terlarut TCA 20\% x } 100}{\text { Protein total }}$ 


\section{Uji Aktivitas Antioksidan (Luisi et al. 2018)}

Pembuatan larutan stok ABTS dengan mereaksikan larutan ABTS $7 \mathrm{mM}$ dan potasium persulfat $2,45 \mathrm{mM}$ perbandingan 1:1 dalam ruangan gelap selama 16 jam pada suhu kamar. Larutan kemudian ditambahkan etanol hingga didapatkan absorbansi $0,700 \pm 0,02$ pada panjang gelombang 734 nm. Larutan sampel sebanyak $1 \mathrm{~mL}(1 \mathrm{mg} /$ $\mathrm{mL}$ ) ditambahkan dalam $2 \mathrm{~mL}$ larutan ABTS kemudian diinkubasi selama 10 menit pada suhu ruang. Absorbansi sampel diukur pada panjang gelombang $734 \mathrm{~nm}$. Aktivitas antioksidan dinyatakan dalam nilai $\mathrm{IC}_{50}$ berdasarkan persamaan kurva regresi penghambatan radikal ABTS pada beberapa seri konsentrasi sampel. Persen penghambatan radikal ABTS dihitung menggunakan rumus berikut:

Persentase inhibisi $=\frac{(\mathrm{Ab}-\mathrm{As})}{\mathrm{Ab}} \times 100 \%$

Keterangan:

$\mathrm{Ab}=$ absorbansi blanko

As $=$ absorbansi sampel

\section{Analisis zeta potensial (Tan dan Chang 2018)}

Penentuan nilai zeta potensial dari sampel kolagen menggunakan alat Zeta Potential Analyzer. Kolagen hasil ekstraksi dilarutkan dalam asam asetat $0,1 \mathrm{M}$ pada konsentrasi $1 \mathrm{mg} / \mathrm{mL}$. Selanjutnya $1 \mathrm{~mL}$ larutan kolagen dipindahkan ke sel kapiler, dan $\mathrm{pH}$ larutan kolagen disesuaikan menjadi 2-6 menggunakan $1 \mathrm{M}$ asam nitrat atau $1 \mathrm{M}$ $\mathrm{KOH}$.

\section{Analisis profil protein kolagen dengan SDS PAGE (Laemmli 1970)}

Sampel ditimbang $10 \mathrm{mg}$ dan dilarutkan dalam $0,5 \mathrm{~mL}$ SDS $10 \%$ lalu diinkubasi selama 1 jam pada suhu $85{ }^{\circ} \mathrm{C}$. Selanjutnya $80 \mu \mathrm{L}$ sampel ditambahkan $20 \mu \mathrm{L}$ buffer sampel (mengandung Tris-HCl, gliserol, SDS, merkaptoetanol dan bromofenol biru) dan dipanaskan selama 5 menit. Sampel diinjeksikan ke dalam gel yang berisi $10 \%$ gel pemisah (separating gel) serta $4 \%$ gel penahan (stacking gel). Elektroforesis dijalankan pada 35 volt $15 \mathrm{~mA}$ selama 6 jam. Proses pewarnaan gel menggunakan larutan pewarna (staining solution) dilakukan selama 1 jam, kemudian gel dibersihkan dengan larutan peluntur (destaining solution) hingga band protein terlihat di permukaan gel. Broad range protein ladder digunakan sebagai penanda protein. Berat molekul protein ditentukan berdasarkan jarak perpindahan protein ke dalam persamaan regresi linier oleh marker protein dengan kisaran berat molekul 10-250 $\mathrm{kDa}$ dari Thermofisher (AS).

\section{Analisis Data}

Analisis nilai rendemen, pola protein, dan zeta potensial dilakukan secara deskriptif. Rancangan percobaan yang digunakan untuk analisis persentase derajat hidrolisis dan aktivitas antioksidan adalah rancangan acak lengkap faktorial (RALF). Perlakuan yang diamati yakni pemberian enzim dengan aktivitas yang berbeda $(4.000 \mathrm{U} / \mathrm{g}, 6.000 \mathrm{U} / \mathrm{g}$ dan $8.000 \mathrm{U} / \mathrm{g}$ ) serta waktu hidrolisis yang berbeda $(60,120,180$ menit) dihitung setelah penambahan enzim papain. Kedua perlakuan tersebut diulang sebanyak tiga kali ulangan. Data yang diperoleh dianalisis menggunakan ANOVA dengan selang kepercayaan 95\% $(\alpha=0,05)$ dan dilakukan uji lanjut duncan pada taraf 5\% menggunakan perangkat lunak SPSS versi 20 .

\section{HASIL DAN PEMBAHASAN Komposisi Kimia Kulit Ikan Nila}

Analisis proksimat meliputi kandungan protein, air, lemak, dan abu. Komposisi kimia kulit ikan dapat dilihat pada Table 1. Kulit ikan nila memiliki kandungan protein lebih tinggi dibandingkan komponen gizi lainnya. Kandungan protein kulit ikan nila berdasarkan berat kering lebih tinggi dibandingkan kandungan protein kulit ikan tuna (Hadinoto dan Idrus 2018) dan kulit ikan gabus (Wulandari 2016), namun lebih rendah dibandingkan kandungan protein kulit ikan patin (Devi et al. 2017). Kandungan protein yang tinggi pada kulit ikan nila membuatnya berpotensi menjadi bahan baku hidrolisat protein kolagen.

Kandungan lemak dan abu pada kulit ikan nila berdasarkan berat kering lebih rendah dibandingkan dengan kandungan 
Table 1 Proximate composition of fish skin

\begin{tabular}{|c|c|c|c|c|c|c|c|c|}
\hline \multirow[t]{2}{*}{ Composition } & \multicolumn{2}{|c|}{ Tilapia $^{1}$ (O. niloticus) } & \multicolumn{2}{|c|}{$\begin{array}{c}\text { Catfish }^{2} \\
\text { (Pangasius pangasius) }\end{array}$} & \multicolumn{2}{|c|}{$\begin{array}{c}\text { Catfish }^{3} \\
\text { (Chana striata) }\end{array}$} & \multicolumn{2}{|c|}{$\begin{array}{c}\text { Tuna }^{4} \\
\text { (Thunnus albacares) }\end{array}$} \\
\hline & $\%(w b)$ & $\%(\mathrm{db})$ & $\%(\mathrm{wb})$ & $\%(\mathrm{db})$ & $\%(w b)$ & $\%(\mathrm{db})$ & $\%(w b)$ & $\%(\mathrm{db})$ \\
\hline Water & $61.38 \pm 0.015$ & - & 66.80 & - & 77.18 & - & 59.31 & - \\
\hline Protein & $35.70 \pm 0.005$ & 92.44 & 19.48 & 97.16 & 20.36 & 89.22 & 27.32 & 67.14 \\
\hline Lipid & $2.02 \pm 0.005$ & 5.23 & 2.33 & 11.62 & 1.42 & 6.22 & 6.17 & 15.16 \\
\hline Ash & $0.11 \pm 0.002$ & 0.28 & 0.14 & 0.70 & 0.47 & 2.06 & 5.73 & 14.08 \\
\hline
\end{tabular}

Note: ${ }^{1}$ Research data; ${ }^{2}$ Devi et al. $2017 ;{ }^{3}$ Wulandari 2016; ${ }^{4}$ Hadinoto and Idrus 2018 ; wb: wet basis; db: dry basis

lemak pada kulit ikan patin (Devi et al. 2017), kulit ikan gabus (Wulandari 2016), dan kulit ikan tuna (Hadinoto dan Idrus 2018). Kadar abu menunjukkan jumlah mineral yang terkandung dalam kulit ikan nila. Komponen lemak dan mineral pada kulit ikan nantinya akan dihilangkan melalui proses praperlakuan.

\section{Rendemen}

Nilai rendemen menunjukkan seberapa efisien bahan baku dapat diubah menjadi produk. Hasil rendemen hidrolisat kolagen yang diperoleh dipengaruhi oleh berbagai faktor di antaranya jenis dan kualitas bahan baku. Zelechowska (2010) menyatakan bahwa waktu penyimpanan dalam kondisi beku memengaruhi jumlah kolagen yang dapat diekstraksi. Semakin lama bahan baku disimpan mengakibatkan semakin sedikit jumlah kolagen yang dapat diekstraksi, dengan penurunan hingga 1,2\% per minggu.

Rendemen hidrolisat kolagen yang diperoleh sebesar $15,17 \pm 0,12 \%$ terhadap bahan baku kulit ikan nila. Hasil penelitian Hartina et al. (2019) menunjukkan rendemen hidrolisat kolagen kulit ikan bandeng yang dihidrolisis menggunakan enzim alkalase dan bromelin selama 60 menit berturut-turut sebesar $6,75 \pm 2,04 \%$ dan $16,89 \pm 0,12 \%$. Hasil penelitian Zhao et al. (2018) menunjukkan nilai rendemen hidrolisat kolagen dari kulit Rana chensinensis yang dihidrolisis menggunakan enzim pepsin sebesar $15,1 \%$. Perbedaan nilai rendemen hidrolisat kolagen pada berbagai spesies menurut Zhang et al. (2007) dapat dipengaruhi oleh proses hidrolisis, spesifisitas enzim protease yang digunakan, serta karakteristik ikatan crosslinking pada kolagen dan hidrolisatnya. Ikatan silang crosslinking pada kolagen bisa mengalami polikondensasi
- CHO pada terminal peptida atau antar molekul yang berdampak pada menurunnya kelarutan kolagen pada kondisi asam.

\section{Derajat Hidrolisis}

Derajat hidrolisis menunjukkan persentase perbandingan jumlah ikatan peptida yang rusak terhadap jumlah ikatan peptida keseluruhan dalam bahan (Bougatef et al. 2012). Semakin tinggi nilai derajat hidrolisis berarti semakin sempurna proses hidrolisis protein yang berjalan. Nilai derajat hidrolisis sering dikaitkan dengan aktivitas biologis pada hidrolisat protein. Persentase derajat hidrolisis dapat dilihat pada Figure 1.

Nilai persentase derajat hidrolisis dari hidrolisat kolagen kulit ikan nila berkisar antara $12,21-34,01 \%$. Hasil analisis ragam menunjukkan bahwa perbedaan waktu hidrolisis, jumlah enzim papain yang diberikan serta interaksi kedua faktor tersebut memberikan pengaruh yang signifikan $(p<0,05)$ terhadap nilai derajat hidrolisis. Berdasarkan hasil uji lanjut Duncan diketahui bahwa perlakuan terbaik adalah waktu hidrolisis selama 120 menit dengan penambahan enzim $8.000 \mathrm{U}$ dengan nilai persentase derajat hidrolisis sebesar 33,94\%. Penelitian Hema et al. (2017) menunjukkan bahwa hidrolisis kolagen kulit ikan Ephinepelus malabaricus menggunakan enzim papain selama 4,25 jam memberikan nilai derajat hidrolisis sebesar $21 \pm 1,03 \%$. Hidrolisat kolagen kulit ikan bandeng menggunakan enzim papain selama 160 menit memiliki nilai derajat hidrolisis sebesar 4,57\% (Baehaki et al. 2015). Hal ini sesuai dengan Jamil et al. (2016) yang menyatakan bahwa nilai derajat hidrolisis pada hidrolisat protein ikan dipengaruhi oleh lama waktu hidrolisis 


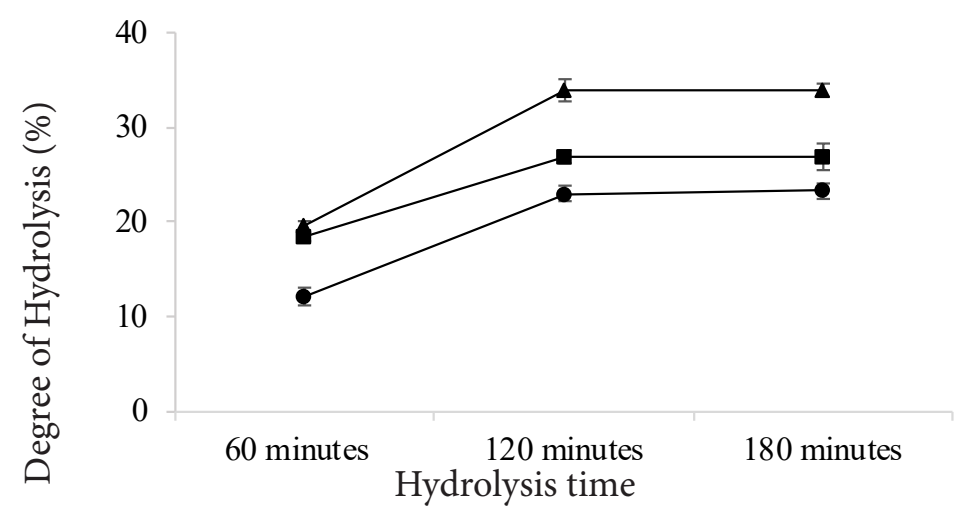

Figure 1 Degree of hydrolysis from tilapia collagen hydrolysate; $\bullet-4000 ; \rightarrow-6000 ; \square 8000$.

Table 2 Degree of hydrolysis of fish collagen

\begin{tabular}{llll}
\hline \multicolumn{1}{c}{ Substrate } & Method & \multicolumn{1}{c}{ Enzyme } & DH (\%) \\
\hline Tilapia skin collagen $^{1}$ & TCA & Papain & $33.94 \pm 1.12$ \\
Milkfish skin collagen $^{2}$ & TCA & Alcalase & 9.14 \\
& & Bromelin & 9.23 \\
Sea cucumber collagen $^{3}$ & TCA & Pepsin & $54.22 \pm 0.47$ \\
Tuna skin collagen $^{4}$ & TCA & Alcalase & $11.49 \pm 1.5$ \\
Catfish skin collagen $^{5}$ & TCA & Papain & 4.75 \\
Snapper skin collagen $^{6}$ & TCA & Papain & $21.00 \pm 1.03$ \\
& & Pepsin & $11.10 \pm 1.40$ \\
\hline
\end{tabular}

Note: ${ }^{1}$ Research data; ${ }^{2}$ Hartina et al. 2019; ${ }^{3}$ Khirzin et al. 2015; ${ }^{4}$ Blanco et al. 2017; ${ }^{5}$ Baehaki et al. 2015; ${ }^{6} \mathrm{Hema}$ et al. 2017

serta konsentrasi enzim yang diberikan. Beberapa hasil penelitian sebelumnya telah melaporkan nilai derajat hidrolisis pada hidrolisat protein ikan (Table 2).

Hasil penelitian juga menunjukkan bahwa nilai derajat hidrolisis mengalami peningkatan seiring dengan makin tingginya jumlah enzim papain yang diberikan. Selama proses hidrolisis, menurut Beveridge (1996) papain akan membelah substrat menjadi produk oleh kelompok histidin dan sistein melalui sisi aktif enzim katalitik. Perubahan struktural yang terjadi yakni gugus sistein (Cys-25) reaktif terikat pada substrat untuk menghasilkan substrat berikatan kovalen dengan enzim tetrahedral. Kelompok histidin (His-159) diprotonasi sehingga mengikat nitrogen yang ada pada substrat. Akibatnya kelompok amina pada substrat berdifusi dan posisinya digantikan oleh molekul air yang pada akhirnya menghidrolisis produk antara (intermediate) sehingga mengembalikan enzim ke bentuk dan fungsi aslinya. Menurut Kristinsson dan Rasco (2000) perubahan yang terjadi pada ikatan peptida pada proses hidrolisis yakni bertambahnya jumlah gugus terionisasi $\left(\mathrm{NH}_{4+}, \mathrm{COO}\right)$ sehingga produk menjadi bersifat hidrofilik, serta terjadi penurunan ukuran molekul rantai polipeptida dan perubahan struktur molekul membentuk struktur yang terbuka terhadap lingkungan.

\section{Aktivitas Antioksidan}

Prinsip pengujian aktivitas antioksidan menggunakan metode ABTS adalah metode kolorimetrik yakni mengukur perubahan warna senyawa radikal setelah direaksikan dengan senyawa antioksidan melalui nilai absorbansi menggunakan spektrofotometri. Warna pada radikal ABTS berkurang akibat terputusnya rantai senyawa radikal serta donor ion hidrogen oleh senyawa antioksidan (Correa et al. 2011). Aktivitas antioksidan dapat dinyatakan dalam bentuk persen 


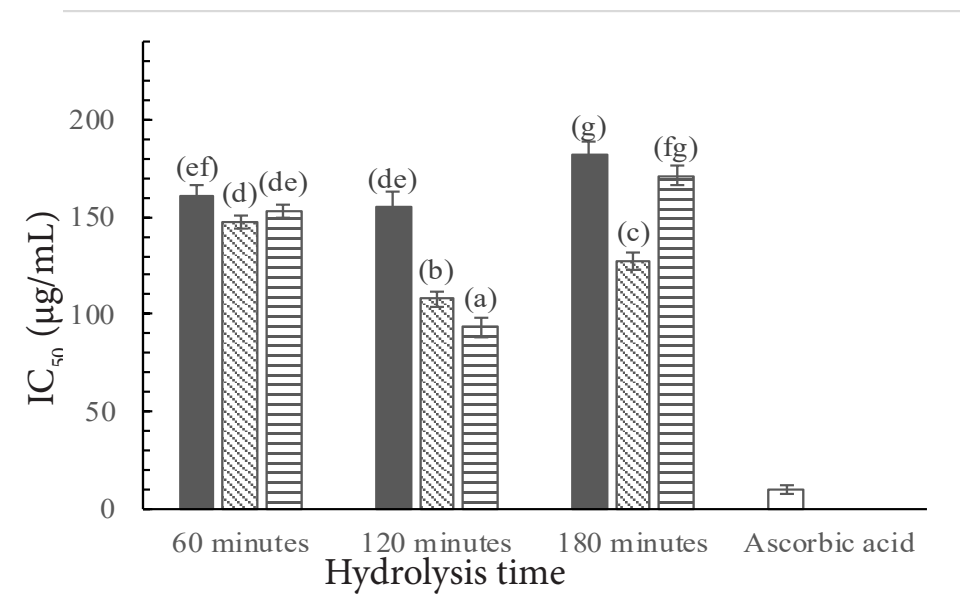

Figure 2 Antioxidant activity of tilapia collagen hydrolisate; $\square$ 4,000; $\square 6,000$; 目 8,000 .

penghambatan maupun $\mathrm{IC}_{50}$ (inhibition concentration 50). $\mathrm{IC}_{50}$ diartikan sebagai jumlah konsentrasi sampel yang dibutuhkan untuk menghambat $50 \%$ dari radikal bebas. Nilai $\mathrm{IC}_{50}$ hidrolisat kolagen kulit ikan nila dapat dilihat pada Figure 2.

Nilai IC $_{50}$ aktivitas antioksidan hidrolisat kolagen kulit ikan nila berkisar antara 93,32$181,84 \mu \mathrm{g} / \mathrm{mL}$, sedangkan nilai $\mathrm{IC}_{50}$ kolagen sebelum dihidrolisis sebesar $836,2 \mu \mathrm{g} / \mathrm{mL}$. Hasil analisis ragam menunjukkan bahwa perbedaan waktu hidrolisis, jumlah enzim yang digunakan serta interaksi antara kedua faktor tersebut memberikan pengaruh yang signifikan $(p<0,05)$ terhadap aktivitas antioksidan. Waktu hidrolisis terbaik yakni selama 120 menit dengan nilai $\mathrm{IC}_{50}$ paling rendah sebesar $93,32 \mu \mathrm{g} / \mathrm{mL}(0,093 \mathrm{mg} / \mathrm{mL})$ pada penambahan enzim sebesar $8.000 \mathrm{U}$. Nilai aktivitas antioksidan tersebut masuk kedalam kategori antioksidan kuat $(<100$ $\mathrm{ppm})$. Semakin rendah nilai $\mathrm{IC}_{50}$ menunjukkan bahwa semakin kuat aktivitas antioksidan dari suatu senyawa. Pada penelitian ini juga dilakukan pengukuran $\mathrm{IC}_{50}$ asam askorbat sebagai kontrol positif dengan nilai yang diperoleh sebesar $10,15 \mu \mathrm{g} / \mathrm{mL}$. Nilai tersebut masih lebih rendah dibandingkan $\mathrm{IC}_{50}$ dari hidrolisat kolagen ikan nila. Hasil penelitian Nurilmala et al. (2020) menunjukkan bahwa hidrolisat kolagen dari kulit tuna memiliki aktivitas antioksidan dengan nilai $\mathrm{IC}_{50}$ sebesar $66,28 \pm 0,12 \mu \mathrm{g} / \mathrm{mL}$. Chalamaiah et al. (2015) melaporkan bahwa hidrolisat protein telur ikan mas yang dihidrolisis dengan enzim yang berbeda yakni tripsin, pepsin dan alkalase memiliki nilai $\mathrm{IC}_{50}$ berturut-turut sebesar 0,186; 0,235; dan 0,301 mg/mL.

Radikal ABTS memiliki sifat lebih reaktif dibandingkan dengan radikal DPPH. Reaksi yang terjadi antara senyawa antioksidan dengan radikal ABTS melibatkan proses transfer elektron tunggal. Pengamatan perubahan warna dari kation radikal biruhijau ABTS yang memiliki serapan gelombang pada $734 \mathrm{~nm}$, telah banyak digunakan untuk mengevaluasi kapasitas antioksidan dari campuran kompleks dan senyawa yang diduga berpotensi sebagai antioksidan. Reaksi penghambatan dan penangkapan radikal bebas ABTS oleh senyawa antioksidan dapat diamati melalui penurunan absorbansi sampel pada gelombang $734 \mathrm{~nm}$. Nilai tersebut berkurang secara proporsional setelah menerima elektron atau hidrogen dari antioksidan (Lu et al. 2010).

\section{Profil Protein}

Hasil elektroforesis kolagen kulit ikan nila dan hidrolisatnya dapat dilihat pada Figure 3. Protein kolagen teridentifikasi dengan adanya rantai a1 dengan berat molekul 129,82 dan a2 dengan berat molekul 100,93. Pita protein dengan berat molekul tinggi misalnya rantai $\beta$ (dimers) dan $\gamma$ (trimers) tidak terlihat pada hasil elektroforesis kolagen kulit ikan nila. Rantai $\alpha 1$ dan $\alpha 2$ merupakan karakteristik kolagen tipe I (Ogawa et al. 2004). Astiana et al. (2016) melaporkan bahwa kolagen kulit ikan ekor kuning (Caesio cuning) yang diekstraksi menggunakan metode ekstraksi asam merupakan kolagen 


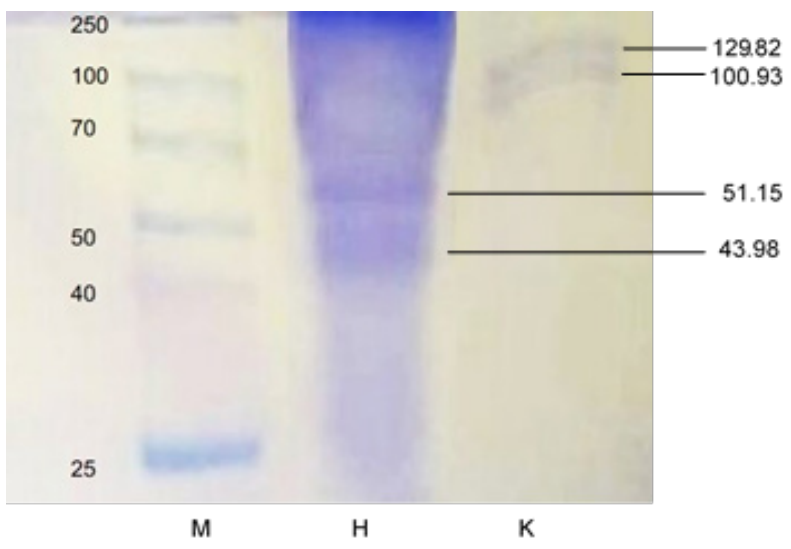

Figure 3 Protein patterns from tilapia collagen $(K)$, tilapia collagen hydrolizate $(H)$, Marker $(M)$

tipe I ditunjukkan oleh adanya rantai $\alpha 1, \alpha 2, \beta$ dan $\gamma$ pada berat molekul berturut-turut 125 , 113, 170-181, dan $208 \mathrm{kDa}$. Hasil penelitian Devi et al. (2017), menunjukkan bahwa kolagen yang diekstraksi dari kulit ikan patin memiliki rantai $\alpha 1$ dan $\alpha 2$ pada berat molekul 94 dan $98 \mathrm{kDa}$. Hasil penelitian lainnya juga menunjukkan ciri kolagen tipe I pada kolagen kulit ikan gabus dengan terlihatnya pita protein $\alpha 1$ dan $\alpha 2$ pada berat molekul 123,35 $\mathrm{kDa}$ dan $88,70 \mathrm{kDa}$.

Hidrolisat protein kolagen kulit ikan nila menunjukkan adanya pita protein dengan berat molekul lebih rendah dari rantai $\alpha$, yang terdeteksi pada nilai berat molekul 51,15 dan 41,98 kDa. Hal ini menunjukkan bahwa protein kolagen mengalami hidrolisis dan terpotong menjadi fragmen protein yang berukuran lebih kecil. Hasil hidrolisat yang diperoleh dipengaruh berbagai faktor meliputi jenis bahan baku, kesesuaian jenis dan konsentrasi enzim yang digunakan, serta waktu hidrolisis. Hasil penelitian Khirzin et al. (2015) menunjukkan bahwa kolagen dari teripang gama yang dihidrolisis menggunakan enzim pepsin memiliki berat molekul 91,91; 44,09; dan 27,64 kDa.

\section{Zeta Potensial}

Zeta potensial merupakan indeks interaksi antar partikel yang dapat digunakan untuk mengukur kestabilan suspensi pada kondisi $\mathrm{pH}$ tertentu. Nilai zeta potensial dapat memberikan gambaran tentang kestabilan suatu bahan dalam mempertahankan sistem koloid. Nilai zeta potensial berpengaruh terhadap kemampuan penghantaran obat dari suatu bahan. Nilai zeta potensial yang besar (positif maupun negatif) mencegah bahan dari proses agregasi. Umumnya nilai zeta potensial lebih dari $\pm 20 \mathrm{mV}$ dinyatakan stabil. Hasil pengujian zeta potensial pada kolagen kulit ikan nila dan hidrolisatnya dapat dilihat pada Figure 4.

Nilai zeta potensial hidrolisat kolagen ikan nila sebesar $-10,9 \mathrm{mV}$. Hasil tersebut menunjukkan bahwa hidrolisat kolagen mampu menjaga kestabilan sistem koloid dari terjadinya flokulasi dan koagulasi. Sistem koloid yang stabil menurut Rogowska et al. (2017) baru dapat dicapai pada nilai zeta potensial lebih dari $\pm 20 \mathrm{mV}$. Nilai zeta potensial 0 hingga $\pm 5 \mathrm{mV}$ pada emulsi/dispersi memungkinkan terjadinya flokulasi atau koagulasi yang tinggi, nilai \pm 10 $\mathrm{mV}$ hingga $\pm 30 \mathrm{mV}$ kestabilan nano partikel baru terbentuk.

Nilai zeta potensial pada hidrolisat kolagen kulit ikan nila bernilai negatif dipengaruhi oleh nilai $\mathrm{pH}$ pada sampel. Sampel hidrolisat kolagen kulit ikan nila dilarutkan dalam akuabides memiliki $\mathrm{pH}$ yang mendekati netral. Hasil penelitian Suryanti et al. (2017) menunjukkan bahwa nilai zeta potensial gelatin kulit ikan nila yang dilarutkan dalam larutan asam asetat dan asam sitrat $3 \%$ berturut-turut sebesar $+14,42$ dan $+14,74$. Menurut Nagarajan et al. (2015) pada kondisi $\mathrm{pH}$ asam (kisaran 2-5) zeta potensial bernilai positif, sedangkan pada $\mathrm{pH}$ cenderung netral (kisaran7-9) zeta potensial bernilai negatif. Nilai zeta potensial ini juga berpengaruh terhadap kemampuan sistem penghantaran obat (drug delivery system). 


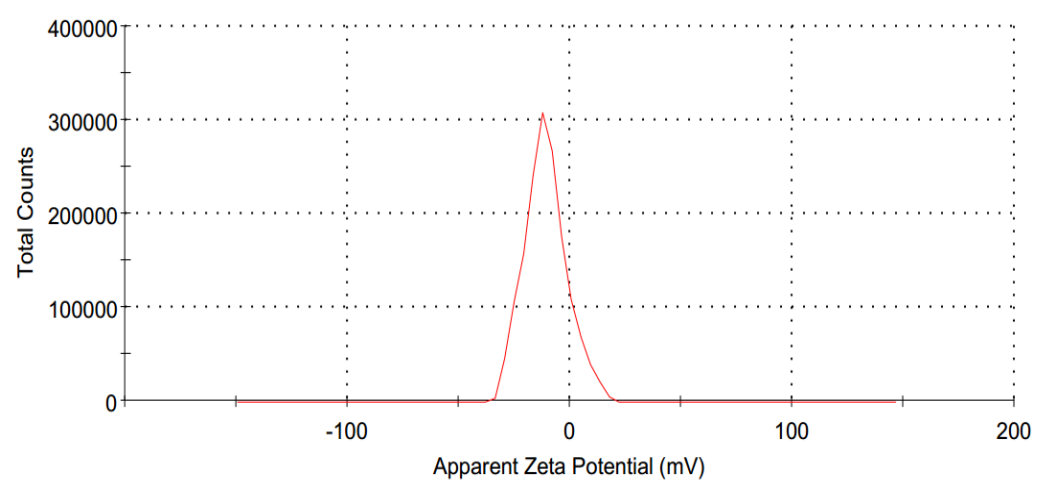

Figure 4 Zeta potential score of tilapia collagen hydrolisate

Rogowska et al. melaporkan bahwa (2017) sistem sediaan nanopartikel bermuatan negatif mampu bertahan dalam aliran darah lebih lama serta memiliki risiko bersifat sitotoksik yang lebih rendah.

\section{KESIMPULAN}

Hidrolisat kolagen kulit ikan nila dengan perlakuan hidrolisis selama 120 menit serta pemberian konsentrasi enzim sebesar 8.000 U memiliki rerata persentase derajat hidrolisis teringgi serta nilai $\mathrm{IC}_{50}$ antioksidan terbaik, termasuk pada kategori senyawa antioksidan kuat.

\section{UCAPAN TERIMA KASIH}

Ucapan terima kasih disampaikan kepada Kementerian Riset dan Teknologi Republik Indonesia/Badan Riset dan Inovasi Nasional atas dukungan pendanaan penelitian melalui program Penelitian Tesis Magister (PTM) tahun anggaran 2020.

\section{DAFTAR PUSTAKA}

Ahmad MG, Setyaningsih I, Trilaksani W. 2019. Formulasi dan bioaktivitas suplemen tablet berbasis Spirulina dan hidrolisat kolagen kulit ikan nila. Jurnal Pengolahan Hasil Perikanan Indonesia. 22(3): 453-463.

Ahmed R, Chun BS. 2018. Subcritical water hydrolysis for the production of bioactive peptides from tuna skin collagen. The Journal of Supercritical Fluids. 141(1): $1-35$.

Astiana I, Nurjanah, Nurhayati T. 2016. Karakteristik kolagen larut asam dari kulit ikan ekor kuning. Jurnal Pengolahan
Hasil Perikanan Indonesia. 16(1): 79-93.

Baehaki A, Nopianti R, Anggraeni S. 2015. Antioxidant activity of skin and bone collagen hydrolyzed from striped catfish (Pangasius pangasius) with papain enzyme. Journal of Chemical and Pharmaceutical Research. 7(11): 131-135.

Beveridge AJ. 1996. A theoretical study of the active sites of papain and S195C rat trypsin: implications for the low reactivity of mutant serine proteinases. Protein Science. 5(7): 1355-1365.

[BKIPM] Badan Karantina Ikan dan Pengendalian Mutu. Statistik Ekspor Nila Tahun 2018 [Internet]. (diunduh pada 10 November 2019) Tersedia pada http:// bkipm.kkp.go.id/bkipmnew/?r=stats/\# ops_volume/E/Kg/m//2018//n m_ umum/Nila

Blanco M, Vazquez JA, Martin RIP, Sotelo CG. 2017. Hydrolysates of fish skin collagen: an opportunity for valorizing fish industry byproducts. Marine Drugs. 15:131-146.

Bougatef, A, Balti R, Haddar A, Jellouli K, Souissi N, Nasri M. 2012. Antioxidant and functional properties of protein hydrolysates of bluefin tuna (Thunnus thynnus) heads as influenced by the extent of enzymatic hydrolysis. Biotechnology and Bioprocess Engineering. 17(4): 841852.

Chalamaiah M, Kumar B, Hemalatha R. Jyothirmayi T. 2012. Fish protein hydrolysates: Proximate composition, amino acid composition, antioxidant activities and applications: a review. Food Chemistry. 135: 3020-3038.

Correa AP, Daroit DJ, Coelho J, Meira SM, 
Lopes FC, Segalin J, Risso PH, Brandelli A. 2011. Antioxidant, antihypertensive and antimicrobial properties of ovine caseinate hydrolyzed with microbial protease. Journal of the Science of Food and Agriculture 91: 2247-2254.

Devi HLNA, Suptijah P, Nurilmala M. 2017. Efektifitas alkali dan asam terhadap mutu kolagen dari kulit ikan patin. Jurnal Pengolahan Hasil Perikanan Indonesia. 20(2): 255-265.

Gadi DS, Trilaksani W, Nurhayati T. 2017. Histologi, ekstraksi dan karakterisasi kolagen gelembung renang ikan cunang Muarenesox talabon. Jurnal Ilmu dan Teknologi Kelautan Tropis. 9(2):665-683.

Hadinoto S, Idrus S. 2018. Proporsi dan Kadar Proksimat Bagian Tubuh Ikan Tuna Ekor Kuning (Thunnus albacares) dari Perairan Maluku. Majalah BIAM (Bahan Alam, Industri, Aneka Pangan, Minyak Atsiri). 14: 51-57

Hartina UMR, Annuar QH, Izzreen NMN, Hasmadi M. 2019. Properties of hydrolysed collagen from the skin of milkfish (Chanos chanos) as affected by different enzymatic treatments. International Journal of Research Science and Management. 6(2): 34-4.

Hema GS, Joshy CG, Shyni K, Chatterjee NS, Ninan J, Mathew S. 2017. Optimization of process parameters for the production of collagen peptides from fish skin (Epinephelus malabaricus) using response surface methodology and its characterization. Journal of Food Science and Technology. 54(2):488-496.

Jamil NH, Halim NRA, Sarbon NM. 2016. Optimization of enzymatic hydrolysis condition and functional properties of eel (Monopterus sp.) protein using response surface methodology (RSM). International Food Research Journal. 23(1): 1-9.

Khirzin MH, Sukarno, Yuliana ND, Fawzya YN, Chasanah E. 2015. Aktivitas inhibitor enzim pengubah angiotensin (ACE) dan antioksidan peptida kolagen dari teripang gama (Stichopus variegatus). Jurnal Pascapanen dan Bioteknologi Kelautan dan Perikanan. 10(1): 27-35.
Kristinsson HG, Rasco BA. 2000. Fish protein hydrolysates: production, biochemical and functional properties. Food Science and Nutrition. 40 (1): 43-81.

Kucharz EJ. 1992. The collagens: Biochemistry and Pathophysiology. Berlin (DEU): Springer-Verlag.

Liu D, Zhang $\mathrm{X}$, Li T, Yang $\mathrm{H}$, Zhang $\mathrm{H}$, Regenstein JM, Zhou P. 2015. Extraction and characterization of acid-and pepsin-soluble collagens from the scales, skins and swim-bladders of grass carp (Ctenopharyngodon idella). Food Bioscience. 9(1): 68-74.

Lu JM, Lin PH, Yao Q, Chen C. 2010. Chemical and molecular mechanisms of antioxidants: experimental approaches and model systems. Journal of Cellular and Molecular Medicine. 14:840-860.

Luisi G, Stefanucci A, Zengin G, Dimamito MP, Mollica A. 2018. Antioxidant and tyrosinase inhibitory in vitro activity of amino acids and small peptides: new hints for the multifaceted treatment of neurologic and metabolic disfunctions. Antioxidants. 8(1): 1-14.

Mendis E, Rajapakse N, Kim SK. 2005. Antioxidant properties of radical scavenging peptides purified from enzymatically prepared fish skin gelatin hydrolysates. Journal of Agricultural and Food Chemistry. 53(3): 581-587.

Murray BA, Fitzgerald RJ. 2007. Angiotensin-I converting enzyme inhibitory peptides derived from food proteins: Biochemistry, bioactivity and production.Current Pharmaceutical Design. 13(8): 773-791.

Mutamimah D, Ibrahim B, Trilaksani W. 2018. Aktivitas antioksidan hidrolisat protein mata ikan tuna (Thunnus sp.) dengan hidrolisis enzimatik. Jurnal Pengolahan Hasil Perikanan Indonesia. 21(3): 522531.

Nagarajan M, Benjakul S, Prodpran T, dan Songtipya P. 2015. Effect pf pHs on properties of bio-nanocomposite based on tilapia skin gelatin and cloisite $\mathrm{Na}+$. International Journal of Biological Macromolecules. 75(4): 388-387.

Najafian L, Babji AS. 2014. Production of bioactive peptides using enzymatic 
hydrolysis and identification antioxidative peptides from patin (Pangasius sutchi) sarcoplasmic protein hydolysate. Journal of Functional Foods. 9(1): 280-289.

Nurilmala M, Hizbullah HH, Karnia E, Kusumaningtyas E, Ochiai Y. 2020. Characterization and antioxidant activity of collagen, gelatin, and the derived peptides from yellowfin tuna (Thunnus albacares) skin. Marine Drugs. 18 (2): 98.

Peranginangin R, Murniyati, Nurhayati, Rahmad W. 2006. Pengolahan Kolagen dari Kulit Ikan Nila. Jakarta (ID): Penebar Swadaya.

Rogowska A, Rafinska K, Pomastowski P, Walczak J, Railean VP, Forajta MB, Buszewski B. Silver nanoparticles functionalized with ampicillin. Electrophoresis. 38 (21): 2757-2764.

Silvestre MPC, Morais HA, Silva VD, Silva MR, Grau. 2013. Degree of hydrolysis and peptide profile of whey proteins using pancreatin. Journal of the Brazilian Chemical Society. 38(1):278-290.

Simamora GRR, Trilaksani W, Uju. 2019. Profiling kolagen gelembung renang ikan patin (Pangasius sp.) melalui proses enzimatis. Jurnal Pengolahan Hasil Perikanan Indonesia. 22(2): 299-310.

Tan Y, Chang SKC. 2018. Isolation and characterization of collagen extracted from channel catfish (Ictalurus punctatus) skin. Food Chemistry. 242: 147-155.

Valko M, Leibfritz D, Moncol J, Cronin MTD, Mazur M, Telser J. 2007. Free radical and antioxidant in normal physiological function and human disease. The International Journal of Biochemistry \& Cell Biology. 39(1): 44-84.

Wu RB, Wu CL, Liu D, Yang XH, Huang JF, Zhang J, Liao BQ. 2018. Antioxidant and anti-freezing peptides from salmon collagen hydrolysate prepared by bacterial extracellular protease. Food Chemistry 248: 346-352.

Wulandari. 2016. Karakterisasi fisikokimia kolagen yang diisolasi dengan metode hidroekstraksi dan stabilisasi nanokolagen kulit ikan gabus (Channa striata) [tesis]. Bogor (ID): Institut Pertanian Bogor.

Zhang Y, Karsten O, Alberto G, Jeanette O. 2013. Effect of pretreatment on enzymatic hydrolysis of bovine collagen and formation of ACE inhibitory peptides. Food Chemistry. 141:2343-2354.

Zhang Y, Ma L, Otte J. 2016. Optimization of hydrolysis conditions for production of angiotensin-converting enzyme inhibitory peptides from basa fish skin using response surface methodology. Aquatic Food Product Technology. 25(5): 684-693.

Zhao Y, Wang Z, Zhang J, Su T. 2018. Extraction and characterization of collagen hydrolysates from the skin of Rana chensinensis. 3 Biotech. 8(3): 181.

Żelechowska E, Sadowska M, Turk M. 2010. Isolation and some properties of collagen from the backbone of Baltic cod (Gadus morhua). Food Hydrocolloids. 24 (4): 325329. 